$$
\text { CONF- } 96 / 202--2
$$

wpf:mrsdusb

\title{
DEPLETED URANIUM OXIDES AND SILICATES AS SPENT NUCLEAR FUEL WASTE PACKAGE FILL MATERIALS
}

\author{
Charles W. Forsberg \\ Oak Ridge National Laboratory* \\ P.O. Box 2008, 105MIT \\ Oak Ridge, Tennessee 37830-6495 \\ Tel: (423) 574-6783 \\ Fax: (423) 574-3431 \\ Email: forsbergcw@ornl.gov
}

September 10, 1996

\author{
Prepared for \\ Materials Research Society 1996 Fall Meeting: Symposium II \\ Scientific Basis For Nuclear Waste Management \\ Materials Research Society \\ Boston, Massachusetts \\ December 2 - 6, 1996 \\ MRS Key Words \\ Waste package, Depleted Uranium, Nuclear Criticality \\ Spent Nuclear Fuel, Repository
}

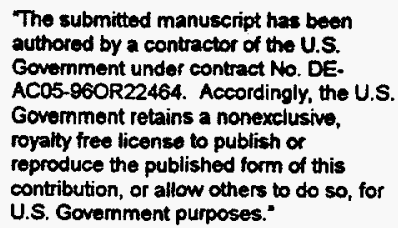

"Managed by Lockheed Martin Energy Research Corp. under contract DE-AC05-960R22464 for the U.S. Department of Energy.

DISTRBITTON OF THIS DOCUMENT IS UNMMUTED $P$

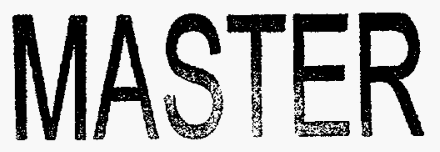




\section{DISCLAIMER}

Portions of this document may be illegible in electronic image products. Images are produced from the best available original document. 


\section{DISCLAIMER}

This report was prepared as an account of work sponsored by an agency of the United States Government. Neither the United States Government nor any agency thereof, nor any of their employees, makes any warranty, express or implied, or assumes any legal liability or responsibility for the accuracy, completeness, or usefulness of any information, apparatus, product, or process disclosed, or represents that its use would not infringe privately owned rights. Reference herein to any specific commercial product, process, or service by trade name, trademark, manufacturer, or otherwise does not necessarily constitute or imply its endorsement, recommendation, or favoring by the United States Government or any agency thereof. The views and opinions of authors expressed herein do not necessarily state or reflect those of the United States Government or any agency thereof. 


\title{
DEPLETED URANIUM OXIDES AND SILICATES AS SPENT NUCLEAR FUEL WASTE PACKAGE FILL MATERIALS
}

\author{
C. W. FORSBERG \\ Oak Ridge National Laboratory, Oak Ridge, TN 37831, forsbergcw@ornl.gov
}

\begin{abstract}
A new repository waste package (WP) concept for spent nuclear fuel (SNF) is being investigated that uses depleted uranium (DU) to improve performance and reduce the uncertainties of geological disposal of SNF. The WP would be filled with SNF and then filled with depleted uranium (DU) $\left(\sim 0.2 \mathrm{wt} \%{ }^{235} \mathrm{U}\right)$ dioxide $\left(\mathrm{UO}_{2}\right)$ or DU silicate-glass beads.

Fission products and actinides can not escape the $\mathrm{SNF} \mathrm{UO}_{2}$ crystals until the $\mathrm{UO}_{2}$ dissolves or is transformed into other chemical species. After WP failure, the DU fill material slows dissolution by three mechanisms: (1) saturation of WP groundwater with DU and suppression of SNF dissolution, (2) maintenance of chemically reducing conditions in the WP that minimize SNF solubility by sacrificial oxidation of DU from the +4 valence state, and (3) evolution of DU to lower-density hydrated uranium silicates. The fill expansion seals the WP from water flow. The DU also isotopically exchanges with SNF uranium as the SNF degrades to reduce long-term nuclear-criticality concerns.
\end{abstract}

\section{INTRODUCTION}

The use of DU as a WP fill material has been investigated. A synthesis of laboratory data on oxides and silicates, hot-cell tests on SNF, geological field data, and other data provide the technical basis for the concept.

\section{MECHANICAL AND CHEMICAL DESCRIPTION}

SNF repository WPs are loaded with SNF and then filled with DU dioxide and/or DU silicateglass beads, which are sufficiently small $(<1 \mathrm{~mm})$ such as to fill coolant channels in the SNF assemblies. The DU enrichment levels are as low as $0.2 \mathrm{wt} \%{ }^{235} \mathrm{U}$. DU is added to the package to reduce the total fissile concentration in the waste package below $1 \mathrm{wt} \%$ of the heavy metal.

Filling has been demonstrated [1] with steel shot on light water reactor (LWR) dummy fuel elements. Canada [2] has conducted extensive tests to fill empty spaces with small particles within WPs containing simulated Canadian Deuterium Uranium (CANDU) SNF. The Canadian WP is a thin-walled, titanium container in which the SNF and fill material must support the WP against external hydrostatic pressure after burial. Canadian tests investigated different particle sizes, different mixtures of particle sizes, alternative fill materials, vibratory filling with different vibration frequencies and amplitudes, and other factors. Tests included successful full-scale WP hydrostatic tests $\left(10 \mathrm{MPa}, 150^{\circ} \mathrm{C}\right)$ of the filled WP.

Representative designs of WPs with DU fill are shown in Table I. These designs cover the expected range of designs from a relatively low-uranium content silicate glass to $\mathrm{UO}_{2}$. 


\begin{tabular}{|c|c|c|}
\hline \multirow[t]{2}{*}{ Property } & \multicolumn{2}{|l|}{ Fill Material } \\
\hline & Low-Uranium Glass* & $\mathrm{UO}_{2}$ \\
\hline SNF (MTIHM***) & 9.96 & 9.96 \\
\hline Solid bead density $\left(\mathrm{g} / \mathrm{cm}^{3}\right)$ & 4.1 & 10.96 \\
\hline DU (wt \%) & 25. & 88. \\
\hline DU mass $(t)$ & 3.43 & 32.3 \\
\hline Ratio of DU to SNF & 0.35 & 3.33 \\
\hline Bead mass $(t)$ & 13.7 & 36.7 \\
\hline Assay (wt \%) of DU ${ }^{235} U$ & 0.2 & 0.2 \\
\hline Equivalent ${ }^{235} \mathrm{U}$ assay (wt \%) of SNF & 1.6 & 1.6 \\
\hline Equivalent ${ }^{235} U$ assay (wt \%) of WP & 1.24 & 0.53 \\
\hline
\end{tabular}

Design basis was the U.S. Multi-Purpose Canister WP system for 21 PWR SNF assemblies [3]. The MPC has an internal volume of $7.9 \mathrm{~m}^{3}$; the SNF baskets have a solid volume of $1.1 \mathrm{~m}^{3}$; and the $21 \mathrm{SNF}$ assemblies have a solid volume of $1.6 \mathrm{~m}^{3}$. A total of $5.2 \mathrm{~m}^{3}$ of the $7.9 \mathrm{~m}^{3}$ of internal volume can be filled with beads.

"Multiple formulations exist for uranium silicate glass [4]

***Metric tons initial heavy metals

\section{REPOSITORY BENEFITS}

The expected repository failure mode is radionuclide migration to the open environment by (1) water leaching of SNF, (2) dissolution of radionuclides and generation of colloids, and (3) transport of those radionuclides in dissolved or colloidal forms to the open environment. Two mechanisms reduce radionuclide release rates: (1) minimize the water flow through the WP and (2) reduce the dissolution of radionuclides into groundwater. 
The use of DU fill reduces each of these mechanisms for radionuclide release. The details of the mechanisms are somewhat different for oxidizing versus reducing groundwater. The choice of DU dioxide or DU silicate-glass depends upon specific SNF type and groundwater conditions.

\section{Reduction of Repository Long-Term Radionuclide Release Rate Under Oxidizing Groundwater Conditions (Yucca Mountain)}

\section{Maintenance of Chemically Reducing Conditions To Minimize SNF $\mathrm{UO}_{2}$ Solubility}

Most fission products and actinides within SNF are incorporated into $\mathrm{UO}_{2}$ spent fuel pellets. Upon WP failure and after entry of groundwater into the WP, these fission products and actinides can not escape the $\mathrm{UO}_{2}$ crystals until the $\mathrm{UO}_{2}$ dissolves or is transformed into other chemical species.

The solubility of uranium in reducing groundwater is very low - about $1 \mathrm{ppb}$ [5]. This solubility is about four orders of magnitude less than the solubility of uranium under oxidizing conditions. Radionuclide releases are extremely limited under chemically reducing conditions [5] because the $\mathrm{UO}_{2}$ does not dissolve and release the radionuclides incorporated within its structure. There are several other beneficial effects. Chemically-reducing conditions minimize the solubility and transport of several other long-lived radionuclides (e.g., neptunium and technetium). Such conditions also reduce the formation and transport of radionuclides as colloids.

With the use of $\mathrm{UO}_{2}$ or uranium silicates with uranium in the +4 valence state, the DU fill ensures chemically reducing conditions within the WP for an extended time independent of external groundwater chemistry. After a WP failure, any oxygen in the groundwater would first encounter the DU before it encounters the SNF. The DU in the +4 chemical state would be oxidized to the +6 chemical state through a series of oxidation steps, thus removing the oxygen from the groundwater.

\section{Saturation of groundwater with $D U$.}

Surrounding the SNF with DU saturates any groundwater within the package with uranium. This saturation slows the SNF dissolution process. DU-saturated groundwater can not dissolve additional SNF uranium.

\section{Creation of Mass Transfer Barriers to Radionuclide Transport}

In oxidizing groundwater, after a loss of chemically reducing conditions in the WP, the addition of uranium silicates may also reduce SNF transformations and dissolution - but by other mechanisms. Because oxidizing groundwater usually contains silicates, the long-term evolution of a WP initially filled with DU dioxide or DU silicate in many ways will be similar. The groundwater can provide silicates to a WP containing only oxides.

Solubility limits. Uranium silicates are less soluble in most groundwaters than are most other uranium compounds. This low solubility reduces the quantity of uranium that can dissolve in a unit of groundwater. The slower dissolution of uranium silicates compared to uranium oxides in oxidizing groundwater implies that longer times will occur before the uranium in the WP is 
dissolved and transported away from the WP. Low rates of dissolution of uranium imply slow formation of flow channels from uranium dissolution through the SNF with slower groundwater flow.

However, the solution is saturated with respect to uranium silicates, not uranium oxides. The availability of silicates can accelerate initial transformations of uranium oxides to less soluble silicates in the SNF and bring about the release of soluble radionuclides to the groundwater during the transformation. The details of the chemical transformation from uranium oxides that are somewhat soluble in oxidizing groundwater to much less soluble uranium silicates determine which actinides and fission products are better isolated after the transformation as compared to before the transformation.

Mass transfer barriers. A DU-silicate-saturated solution can form insoluble, protective layers of uranium silicates over the $\mathrm{UO}_{2}$ crystals within the SNF. This phenomenon is expected to slow uranium alteration and dissolution after initial dissolution of surfaces and has been observed in natural uranium ore deposits under oxidizing groundwater conditions [6]. Any surface silicates that are formed are stable because the groundwater is saturated in uranium silicates that are thermodynamically stable in oxidizing groundwater.

\section{Protection Against Variable Groundwater Chemistry}

The use of DU, particularly $\mathrm{UO}_{2}$, provides a mechanism to counteract any unexpected changes in groundwater that may accelerate degradation of the SNF. Groundwater chemistry can change because of climatic changes and human activities (e.g., irrigation, groundwater pumping, liquid waste injection, etc). The $\mathrm{DU} \mathrm{UO}_{2}$ acts as a sacrificial chemical to absorb changes in groundwater chemistry and delay their effects on the $\mathrm{SNF} \mathrm{UO}_{2}$.

\section{Minimization of Groundwater Flow in WP}

DU fill lowers the hydraulic conductivity within the WP and thus ensures low groundwater flow rates inside the WP. Water flow is the primary mechanism for the transport of radionuclides to the open environment. The release of many radionuclides is controlled by solubility limits. Other radionuclides may be transported by colloids. The slower the flow of groundwater, the slower the transport of radionuclides.

During oxidizing conditions, $\mathrm{UO}_{2}$ will oxidize to higher valence-state uranium oxides which have lower densities [7]. In oxidizing groundwater, the DU oxide will evolve to lower-density, hydrated uranium oxides. Silicates and hydrated uranium oxides further evolve to hydrated uranium silicates. These changes have been observed in the laboratory and in uranium ore deposits $[8,9]$. This volume expansion fills void space and creates a self-sealing WP and thus minimizes water flow. Figure 1 shows this evolutionary sequence as it has been observed in natural uranium ore bodies with oxidizing groundwater [10]. Because of the high surface area of the beads, they will expand and choke off water flow before the SNF uranium evolves to hydrated uranium silicates. Expansion of the fill can be controlled by the choice of fill material. 


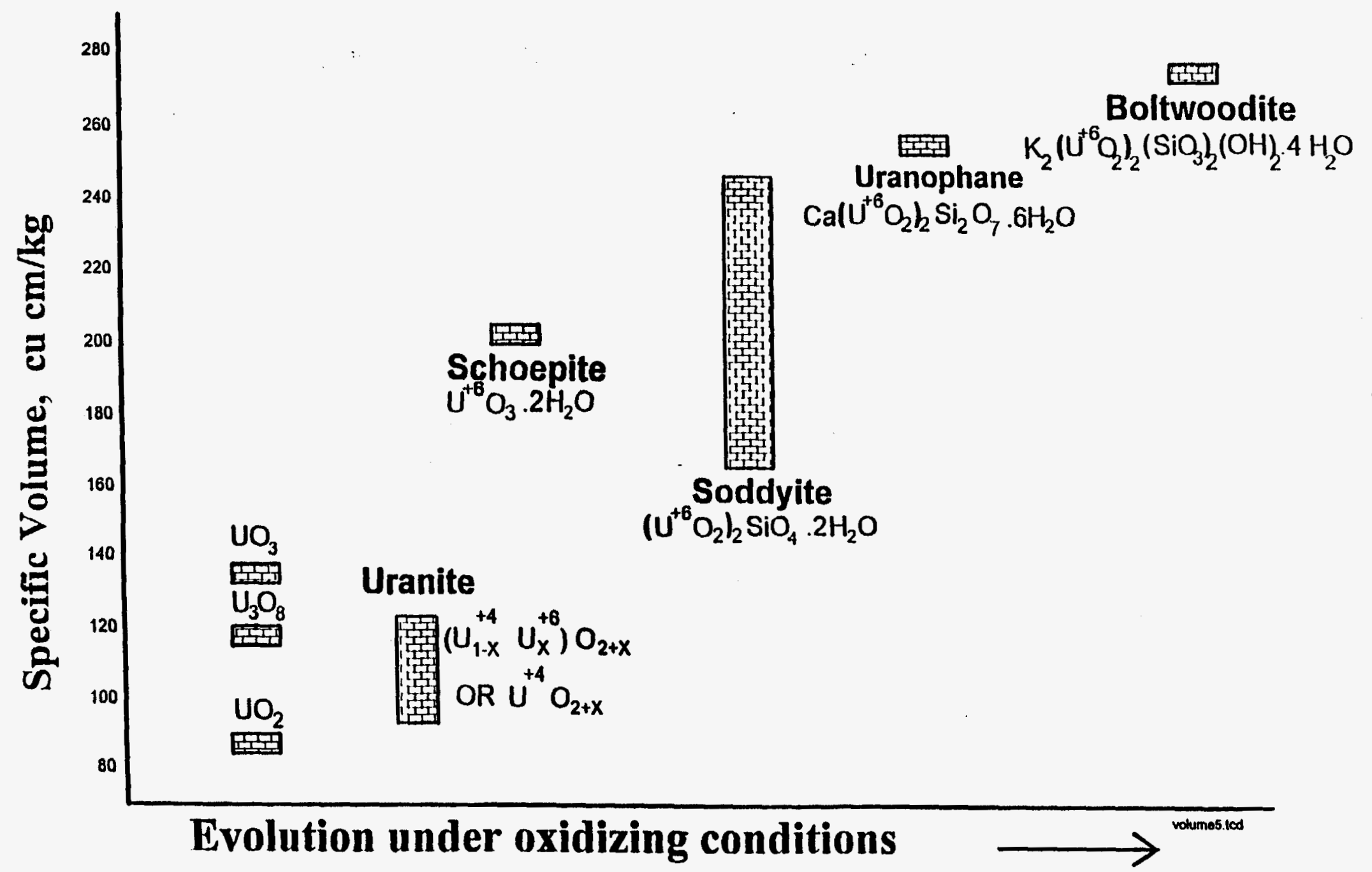

Fig. 1. Specific volume of selected uranium minerals versus evolution over time in oxidizing groundwater. 


\section{Reduction of Repository Long-Term Radionuclide Release Rate Under Reducing Groundwater Conditions}

With chemically-reducing groundwater, $\mathrm{UO}_{2}$ fill is preferred. DU dioxide helps maintain within the WP strong chemically reducing conditions that minimize the oxidation and dissolution of SNF $\mathrm{UO}_{2}$. The DU saturates the local WP groundwater with uranium; this saturation effect further depresses dissolution of SNF $\mathrm{UO}_{2}$.

\section{Reduced Potential For Repository Nuclear Criticality}

As a fill material DU reduces the potential for repository nuclear criticality events. Long-term, low-power, repository nuclear-criticality events are a major concern because they generate heat that (1) accelerates degradation of WPs and (2) accelerates the water movement that may transport radionuclides to the environment.

Criticality is prevented in a repository by neutron absorbers and geometric spacing of fissile materials. Neutron absorbers include ${ }^{238} \mathrm{U}$, boron, gadolinium, and other materials. Neutron absorbers (except ${ }^{238} \mathrm{U}$ ) leach from WPs and travel at rates different from the SNF uranium through the geologic media because of the different chemistries of the absorbers in groundwater. The only neutron absorber that does not separate from ${ }^{235} \mathrm{U}$ over geological time frames is ${ }^{238} \mathrm{U}$. This phenomenon creates the potential for criticality events if the fissile concentration in the repository SNF is sufficiently high. That the fissile content of LWR SNF is sufficient to cause nuclear criticality can be demonstrated by comparing the expected fissile concentrations in the repository $(1.47 \mathrm{wt} \%)$ with fissile concentrations at shutdown $(1.3 \mathrm{wt} \%)$ in naturally occurring reactors [11] in the Oklo mining district in Gabon, Africa. Theoretical analysis yields similar conclusions [12].

Whether nuclear criticality will, in fact, occur in a specific repository depends upon the longterm evolution of the chemical conditions. The addition of DU as a SNF WP fill lowers the uranium enrichment in each waste package and, consequently, in the repository as a whole below $1 \mathrm{wt} \%$. Nuclear criticality can not occur with such low uranium enrichment levels in a geological environment [12].

In LWR SNF, half or more of the fissile material is ${ }^{239} \mathrm{Pu}$. The foregoing analysis is based on the assumption that plutonium remains with the uranium until the major plutonium isotope $\left({ }^{239} \mathrm{Pu}\right)$ decays to ${ }^{235} \mathrm{U}$ and can be isotopically diluted by the DU. This is ensured if the rate of plutonium decay to uranium is faster than the rate of dissolution and transport of uranium within the repository. The primary plutonium isotope, ${ }^{239} \mathrm{Pu}$, has a half-life of 24,000 years (i.e., the decay rate is $3 \times 10^{-5} /$ year).

Performance assessments indicate that plutonium migration is slow in most geological environments. Uranium migration is extremely slow in reducing groundwater; thus, the uranium will remain near the plutonium until the plutonium decays to ${ }^{235} \mathrm{U}$ and is isotopically mixed in the groundwater. In oxidizing groundwater, uranium is more mobile; however, uranium silicates are several orders of magnitude less mobile than many other compounds. Most groundwater contains silicates; thus, formation of uranium silicates from uranium oxides would be expected to slow uranium transport sufficiently to allow plutonium decay to uranium and isotopic dilution of the SNF uranium from plutonium with the DU. Higher assurance of criticality control may be 
achieved by including within the WP system some uranium as uranium silicates or use of excess DU in the WP.

\section{BASIS OF DESIGN}

The central problem of repository design is how to predict long-term performance. Because the kinetic dissolution mechanisms of SNF degradation may be temperature dependent, results from accelerated testing of materials are difficult to interpret. The use of natural materials in WPs can minimize these uncertainties.

Uranium dioxide is currently evolving into hydrated uranium silicate minerals in multiple ore deposits with conditions similar to those of the proposed Yucca Mountain repository. Geological data on the performance of $\mathrm{UO}_{2}$ over millions of years can be combined with laboratory data to provide estimates of WP performance. The use of natural WP fill materials reduces the limitations of using short-term laboratory experiments to predict repository performance for very-long times.

\section{MANAGEMENT OF DEPLETED URANIUM}

For LWR fuel production, natural uranium with a ${ }^{235} \mathrm{U}$ content of $0.71 \%$ is separated into an enriched uranium fraction with the by-product production of 4 to 6 tons of DU per ton of enriched uranium. Currently, there is no significant use for this material. In the United States, about $400,000 \mathrm{t}$ of DU is in storage.

If this material is declared a waste, existing regulatory requirements indicate that some type of geological disposal will be required $[13,14]$. Use of DU within SNF WPs eliminates the separate, not insignificant, cost of disposal of this material.

\section{CONCLUSIONS}

DU inside the WP creates the potential for major improvements in repository performance, provides higher assurance of WP performance based on uranium geochemistry and provides a method to reduce the potential for nuclear criticality in a repository. As a new concept [4], significant uncertainties exist.

\section{REFERENCES}

1. J. A. Cogar, Waste Package Filler Material Testing Report, BBA000000-01717-250000008REV00, U.S. Department of Energy, Las Vegas, Nevada (April 22, 1996).

2. J. L. Crosthwaite, The Performance Assessment and Ranking of Container Design Options for the Canadian Nuclear Fuel Waste Management Program. TR-500, COG-93-410, Atomic Energy of Canada Limited Research Co.(1994)

3. U.S. Department of Energy, Office of Civilian Radioactive Waste Management, MultiPurpose Canister System Evaluation: A Systems Engineering Approach, Washington, D.C. (September 1994). 
4. C. W. Forsberg, et. al., DUSCOBS - A Depleted-Uranium Silicate Backfill For Transport, Storage, and Disposal of Spent Nuclear Fuel, ORNL/TM-13045, Oak Ridge National Laboratory, Oak Ridge, TN (November, 1995).

5. J. A. T. Smellie, F. Karlsson, and B. Grundfelt., Proc. GEOVAL'94: Validation Through Model Testing, Nuclear Energy Agency, Organization for Economic Co-operation and Development, Paris, France (1995), p.363-385.

6. W. M. Murphy, Technology Today (June 1992).

7. D. K. Smith, B. E. Schettz, C. A. F. Anderson, and K. L. Smith, Uranium, 1, (1982), p 79.

8. E. C. Pearcy, J. D. Prikryl, W. M. Murphy, and B. W. Leslie, Applied Geochemistry, 9, (1994), 713-732.

9. W. M. Murphy and E. C. Pearcy, Mat Res. Soc. Symp. Proc., 257, (1992), p 521-527.

10. W. M. Murphy, Radwaste Mag., 2 (6), (November 1995), p 44.

11. International Atomic Energy Agency, Natural Fission Reactors, Proc. of a Mtg. of the Technical Committee on Natural Fission Reactors, Paris France, December 19-21, 1977, Vienna, Austria (1978).

12. S. R. Naudet, IAEA-TC-1 19/22, Natural Fission Reactors, Proc. of a Meeting of the Technical Committee on Natural Fission Reactors, Paris, France, December 19-21, 1977, International Atomic Energy Agency, Vienna, Austria (1978), p 589-599.

13. U.S. Nuclear Regulatory Commission, Safety Evaluation Report for the Claiborne Enrichment Center, Homer, Louisiana, Docket No. 70-3070, NUREG-1491, Washington, D.C. (January 1994).

14. J. W. N. Hickey, Letter from J. Hickey, Chief Fuel Cycle Safety Branch, U.S. Nuclear Regulatory Commission To Louisiana Energy Services, L. P., Docket No. 70-3070, U.S. Nuclear Regulatory Commission, Washington, D.C. (September 22, 1992). 